\title{
PERBANDINGAN KADAR HDL DAN LDL AKSEPTOR DEPO MEDROKSIPROGESTERON ASETAT DENGAN IUD
}

\author{
Suci Syahril ${ }^{1)}$, Meldafia Idaman ${ }^{2)}$, Dewi Fransisca ${ }^{3)}$ \\ ${ }^{1,2,3}$ Prodi D3 Kebidanan, STIKes Syedza Saintika, Jl. Prof.DR. Hamka no 228 Air Tawar Timur \\ suci barboa@,rocketmail.com
}

Diterima: September 2018 Diterbitkan: Desember 2018

\begin{abstract}
Abstrak
Penggunaan kontrasepsi Depo Medroksiprogesteron Asetat (DMPA) semakin meningkat akhir-akhir ini, namun beberapa studi menemukan adanya efek samping peningkatan berat badan serta perubahan pada metabolisme lipid. Oleh sebab itu sekitar 35\% akseptor DMPA pada satu tahun pertama menghentikan penggunaan DMPA. Tujuan penelitian ini adalah untuk mengetahui perbandingan kadar profil lipid antara akseptor DMPA dengan akseptor IUD. Penelitian ini adalah studi observasional dengan desain Cross Sectional. Penelitian dilakukan di Wilayah Kerja Puskesmas Lubuk Buaya Padang dan di laboratorium Bagian Biokimia Fakultas Kedokteran Universitas Andalas dari Januari-September 2016. Subjek penelitian terdiri dari dua kelompok, masing-masing 26 subjek. Pemeriksaan LDL dan HDL dilakukan dengan metode CHOD-PAP. Data dianalisis menggunakan uji $\mathrm{t}$ dengan nilai $\mathrm{p}<0.05$ dianggap bermakna secara

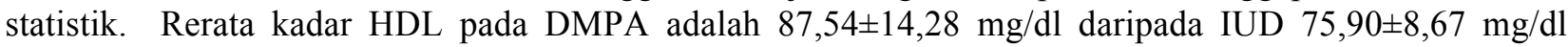
dengan nilai $\mathrm{p}<0,05$ (perbedaan bermakna). Kadar LDL tidak bermakna antara akseptor DMPA dan IUD $(\mathrm{p}>0,05)$. Kesimpulan penelitian ini adalah terdapat perbedaan yang bermakna rerata kadar HDL pada DMPA dan IUD, sedangkan kadar HDL tidak bermakna. Secara klinis profil lipid pada kedua kelompok dalam keadaan normal.
\end{abstract}

Kata kunci: LDL, HDL, Kontrasepsi Depo Medroksiprogesteron Asetat, IUD

\begin{abstract}
The use of contraceptive depot medroxyprogesterone acetate (DMPA) increasing lately, but some studies suggest has the side effects of weight gain and contraceptives that have side effect in lipid metabolism. Therefore, about 35\% of acceptors of DMPA in the first year to stop the use of DMPA. The objective of this study was to determine the differences of lipid profile between acceptors DMPA with acceptors IUD. This was a obcervational study with cross sectional study. The study wasdone at health center Lubuk Buaya in Padang and at laboratory of Biochemistry Departement in Medical Faculty of Andalas University from Januari until September 2016. The subjects were consisted of two groups, each group had 26 subjects. The examination for $L D L$ and HDL used an enzymatic colorimetric method CHOD-PAP. Data was analyzed using analysis of t-test with $p<0.05$ was considered to be significantly different. $H D L$

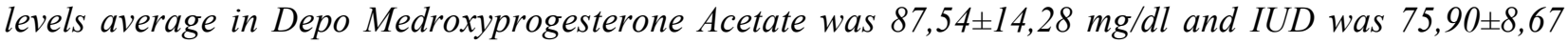
$\mathrm{mg} / \mathrm{dl}$ with $p<0.05$ (significantly difference). Levels of LDL means there is no significantly difference between DMPA and IUD acceptors ( $p>0.05$ ). This research concluded that there is a significant difference on average levels of HDL in the Depo Medroxyprogesterone Acetate and IUD but levels of LDL there is no significantly difference. The clinically lipid profile in the two groups is in normal range.
\end{abstract}

Key Words: LDL, HDL,, Depo Medroxyprogesterone Acetate, IUD 


\section{PENDAHULUAN}

Indonesia merupakan negara berkembang dengan jumlah penduduk berada pada posisi keempat di dunia dengan laju pertumbuhan penduduk yang masih relatif tinggi. Untuk mengatasi salah satu masalah kependudukan tersebut, Pelaksanaan program KB merupakan salah satu prioritas utama dalam rangka menekan laju pertumbuhan penduduk. Proporsi penggunaan kontrasepsi di Indonesia menurut Data Riskesdas tahun 2013 menunjukkan bahwa pada wanita usia 15 49 tahun dengan status kawin sebesar 59,36 $\%$ menggunakan KB modern (implant, MOW, MOP, IUD, kondom, suntikan, pil), $0,40 \%$ menggunakan metode $\mathrm{KB}$ tradisonal (menyusui/MAL, pantang berkala/kalender, senggama terputus, lainnya), $24,72 \%$ pernah melakukan KB, dan $15,52 \%$ tidak pernah melakukan KB (Riset Kesehatan Dasar, 2013).

Berdasarkan data yang diperoleh dari Dinas Kesehatan Kota Provinsi Sumatera Barat menunjukkan pada tahun 2014 jumlah PUS 17.205.500 peserta KB aktif sebanyak 97.428 .000 orang $(56,6 \%)$ dengan rincian peserta yang menggunakan IUD sebesar 8,01 $\%$, MOW sebesar 2,55\%, MOP sebesar $0,31 \%$, kondom sebesar 7,15\%, implant sebesar 4,74\%, suntik sebesar 53,55\%, dan pil sebesar 23,72\% (Dinas Kesehatan Kota Padang, 2014).

Salah satu metode kontrasepsi suntikan hormonal yang dianggap cukup ideal adalah kontrasepsi suntik Depo Medroksi Progesterone Asetat (DMPA). Hal ini dikarenakan kontrasepsi suntik bersifat aman, sederhana, efektif, dan dapat dipakai pada pasca persalinan. Mengingat jumlah akseptor kontrasepsi suntikan semakin meningkat, maka perlu diwaspadai dan antisipasi kemungkinan efek samping yang dapat terjadi. Efek sampingnya antara lain, gangguan haid seperti (siklus memendek atau memanjang, perdarahan spooting, tidak haid sama sekali), penambahan berat badan, begitu juga pada penggunaan jangka panjang terjadi perubahan pada lipid serum, penurunan densitas tulang, gangguan emosi, sakit kepala, nervositas, jerawat dan juga dapat menimbulkan kekeringan pada vagina dan menurunkan libido (Baziad, 2008).

Disamping memiliki efek kontrasepsi ternyata kontrasepsi suntik juga memiliki pengaruh terhadap metabolisme lemak, khususnya lipoprotein. Perubahan metabolisme lemak yang terjadi karena adanya pengaruh hormonal sehingga menyebabkan gangguan keseimbangan profil lipid dalam tubuh atau dislipidemia yang pemakaian jangka panjang dapat menjadi faktor risiko terjadinya penyakit atherosclerosis (Jhon, 2006).

Beberapa penelitian sebelumnya telah meneliti mengenai pengaruh penggunaan jangka panjang dari DMPA terhadap metabolisme lipid, yaitu pada 60 wanita di Nepal yang telah menggunakan lebih dari 2 tahun menunjukkan bahwa kadar trigliserida, kolesterol total dan Low Density Lipoprotein (LDL) lebih tinggi daripada non akseptor, sedangkan kadar High Density Lipoprotein (HDL) menurun. Adanya hal tersebut maka dapat disimpulkan DMPA dapat menyebabkan perubahan metabolisme lipid yang dapat meningkatkan resiko penyakit kardiovaskular (Yadav, et.al., 2011).

Faddah, 2005 pada penelitiannya di Mesir tentang perubahan jangka panjang yaitu selama 4 tahun Depo Medroksiprogesteron Asetat diperoleh peningkatan kadar LDL (4,5 $\mathrm{mg} / \mathrm{dl})$, kolesterol total $(2,2 \mathrm{mg} / \mathrm{dl})$ dan penurunan kadar HDL (5,7 mg/dl) sedangkan kadar trigliserida tidak signifikan. Peningkatan kadar LDL dan penurunan kadar HDL merupakan prediktor kuat terhadap penyakit kardiovaskular (Faddah, et. al., 2005). Penelitian Barenson, 2009 menyebutkan penggunaan DMPA selama 6 bulan dapat meningkatkan rasio LDL/HDL kolesterol 9 (Berenson, Rahman, \& Wilkinson, 2009).

\section{METODE}

Jenis penelitian ini Observasional dengan pendekatan Crossectional. Dilakukan di Laboratorium Biokimia Fakultas Kedokteran Universitas Andalas Padang. Waktu penelitian pada bulan Januari sampai September 2016. Populasi dalam penelitian ini adalah semua akseptor Depo Medroksiprogesteron Asetat dan IUD dengan 
Jumlah sampel sebanyak 52 orang. Pengambilan sampel dilakukan secara consecutive sampling. Pemeriksaan kadar profil lipid dengan metoda Enzimatis Kolometri (GPO-PAP) dan (CHOD-PAP). Data dianalisis secara univariat dan bivariat.

\section{HASIL DAN PEMBAHASAN}

Setelah dilakukan observasi, terhadap 52 sampel, terdiri dari 26 subjek akseptor DMPA dan 26 subjek akseptor IUD. Maka didapatkan karakteristik responden dapat dilihat pada gambar dibawah ini:

1. Perbandingan Kadar HDL dan LDL akseptor DMPA dan IUD

\begin{tabular}{lccll}
\hline Variabel & $\mathbf{n}$ & Mean \pm SD & Mean \pm SD & P \\
\hline HDL & 52 & $87,54 \pm$ & $75,90 \pm 8,67$ & \\
LDL & & 14,28 & 0,01 \\
& & $97,73 \pm$ & $91,22 \pm 14,53$ & \\
& & 21,74 & 0,21
\end{tabular}

Pada akseptor DMPA rata-rata \pm SD pada kadar HDL DMPA rata-rata \pm SD yaitu $87,54 \pm 14,282 \mathrm{mg} / \mathrm{dl}$, kadar HDL IUD ratarata \pm SD yaitu $75,90 \pm 8,679 \mathrm{mg} / \mathrm{dl}$ dengan $p=0,01(p<0,05)$, dan kadar LDL DMPA rata-rata \pm SD yaitu $97,73 \pm 21,746 \mathrm{mg} / \mathrm{dl}$, kadar LDL IUD yaitu rata-rata \pm SD $91,22 \pm 14,539 \mathrm{mg} / \mathrm{dl}$ dengan $p=0,210$ $(p>0,05)$. Hasil ini memperlihatkan bahwa pada kadar LDL tidak terdapat hubungan yang bermakna, sedangkan dengan kadar HDL yang terdapat hubungan yang bermakna.

\section{a. Kadar HDL}

Sebuah penelitian yang dilakukan oleh Estruch (2008) yang dilakukan terhadap 772 responden dengan diet tinggi serat menunjukkan adanya peningkatan kadar kolesterol HDL yang bermakna dengan nilai $\mathrm{p} 0,02$.

Pada hasil penelitian ini terdapat perbedaan yang bermakna antara kedua kelompok secara statistik, walaupun demikian secara klinis kadar HDL meningkat. Akan tetapi banyak faktor yang mempengaruhi kadar HDL diantaranya adalah umur. Umur responden pada penelitian ini dibatasi 20-35 tahun dengan rata-rata umur responden Depo Medroksi Progesteron Asetat yaitu $(30,85 \pm 5,049)$ sedangkan IUD yaitu $(37,04 \pm 2,08)$ sehingga tidak mempengaruhi kadar HDL yaitu masih dalam batas normal. Namun, peningkatan kolesterol HDL kemungkinan terjadi karena adanya kondisi asupan zat gizi subjek penelitian yang tidak dibatasi, dan aktivitas fisiknya juga tidak dibatasi. Kondisi tersebut memungkinkan seluruh konsumsi dan asupan gizi yang diperlukan terpenuhi, termasuk keperluan antioksidan melalui vitamin $C$, vitamin $\mathrm{E}$, dan vitamin A juga terpenuhi sehingga kolesterol HDL ikut meningkat.

\section{b. Kadar LDL}

Beberapa penelitian membuktikan bahwa pemakaian kontrasepsi hormonal progesteron dapat menaikkan kadar LDL sebelum dan sesudah pemakaian (Fathi, et. al., 2008). Penelitian Berenson, Rahman dan Wilkinson, 2009 bahwa terjadi kenaikan LDL dan penurunan HDL pada 6 bulan pemakaian kontrasepsi hormonal DMPA sehingga terjadi peningkatan rasio LDL/HDL secara signifikan. Namun hal ini tidak berlangsung lama, penurunan rasio LDL/HDL terjadi dan turun secara signifikan setelah 18 bulan -24 bulan

Yadav, et. al. (2011) dalam penelitiannya mengenai efek jangka panjang penggunaan Depo Medroksi Progesteron Asetat pada 60 akseptor di Nepal menemukan bahwa LDL pada pengguna Depo Medroksi Progesteron Asetat mengalami peningkatan secara signifikan dibanding kelompok kontrol. Pada penelitian yang dilakukan Sanger, Loho dan Wirasti, 2008 yang mengukur kadar LDL pada saat $1,3,6,9$ dan 12 bulan setelah penggunaan DMPA tidak ditemukan perubahan kadar LDL secara bermakna. Hasil penelitian tersebut sesuai dengan penelitian AlYaouzbaki (2011) yang menyebutkan bahwa tidak terdapat perbedaan kadar LDL yang signifikan antara pengguna DMPA dan bukan pengguna DMPA. Kolesterol LDL sendiri merupakan lipoprotein yang bertanggung jawab membawa serum kolesterol kedalam sel-sel pembuluh darah. Fungsi ini menyebabkan 
kolesterol LDL merupakan salah satu petanda untuk penyakit kardiovaskuler seperti penyakit jantung koroner.

Penelitian yang dilakukan oleh Jamil \& Siddiq (2012) mengenai penggunaan kontrasepsi yang meningkatkan resiko penyakit kardiovaskuler menyebutkan bahwa tidak terdapat perbedaan LDL yang signifikan antara pengguna DMPA dan implant. Selain dari itu, penulis tidak mengetahui kadar LDL responden sebelum menggunakan kontrasepsi sehingga kenaikan yang mungkin terjadi tidak dapat diketahui. Tidak terdapat perbedaan kadar LDL ratarata yang bermakna antara ke dua jenis kontrasepsi menunjukkan bahwa kontrasepsi hormonal progesteron tidak mempunyai pengaruh terhadap kadar LDL.

\section{KESIMPULAN}

Kesimpulan penelitian ini terdapat perbedaan yang bermakna rerata kadar HDL pada DMPA dan IUD, sedangkan kadar trigliserida, kolesterol total dan LDL tidak bermakna. Secara klinis profil lipid pada kedua kelompok dalam keadaan normal. Diharapkan pada peneliti selanjutnya untuk melakukan penelitian pengukuran pada intake (asupan makanan) responden yang dapat mempengaruhi kadar profil lipid. Diharapkan juga kepada petugas kesehatan khususnya Bidan untuk memberikan konseling tentang $\mathrm{KB}$ hormonal baik keuntungan maupun efek samping yang ditimbulkan. Pada akseptor suntik DMPA dianjurkan untuk mengurangi mengkonsumsi makanan yang dapat meningkatkan profil lipid serta perlunya dilakukan pemeriksaan profil lipid darah setiap tahun terhadap semua akseptor kontrasepsi suntik hormonal jangka panjang $>2$ tahun.

\section{UCAPAN TERIMA KASIH}

Penulis mengucapkan terima kasih untuk semua pihak yang telah membantu dalam penelitian ini.

\section{DAFTAR PUSTAKA}

Al-Youbazki WB. C-Reactive Protein And Lipid Profile Among Depomedroksiprogesteron Asetat
Injection Users, College Of Medicine University Of Mosul Irak: 2011.

Baziad, Ali. Kontrasepsi Hormonal. Edisi I. Jilid II. PT. Bina Pustaka Sarwono

Prawiroharjo. Jakarta: 2008.

Berenson, A.B., Rahman, M. and Wilkinson, G. 'Effect of Injectable and oral contraceptives on serum Lipids', Obstetrics \& Gynecology: 2009:114(4), pp. 786-794. doi: 10.1097/aog.0b013e3181b76bea.

Dinas Kesehatan Kota Jumlah Peserta KB Baru dan Aktif Kecamatan dan Puskesmas. Kabupaten / kota Padang Sumatera Barat: 2014.

Estruch, R. Martinez - Gonzales, MA. Corella, D. Basora - Gallisa, J. Ruiz, GV. Covas, MI. Fiol, M. Gomez, GE. Sabater, MCL., Escoda, R. "Effect Of Dietary Fibre Intake On Risk Factors For Cardiovascular Disease In Subjects At High Risk". Journal of Epidemiology and Community Health. BMJ Publishing Group 200963 (7), pp. 582. $<10.1136 /$ jech.2008.082214>.

Faddah, L., Al-Rehany, M., Abdel-Hamid, N. and Bakeet, A. 'Oxidative stress, lipid profile and liver functions in average Egyptian long term Depo Medroxy Progesterone acetate (DMPA) users', Molecules: 2005:10(9), pp. 1145-1152. doi: 10.3390/10091145.

Fathi, NA. Ezz-Eldin, AM. Mosad, E. Bakry, RM. Hamed, HB. Ahmed, S. Mahmoud, M. Rashed HAG and Abdullah, F. "Diagnostic performance and predictive value of rheumatoid factor Anti-CyclicCitrullinated Peptide Antibodies And HlaDrb1 Locus Genes In Rheumatoid Arthritis". International Archives Of Medicine: 2008.

Jamil, S. Siddiq, A. 'Comparison of CVD risk associated with the long term use of contraceptives in Young Females', Journal of Applied Pharmaceutical Science.doi:10.7324/japs.2012.21111.

MF. Jhon, Adam. Ilmu Penyakit Dalam. Edisi IV. Jilid III. Pusat Penerbitan Departemen Penyakit Dalam Fakultas Kedokteran Universitas Indonesia. Jakarta: 2006. 
Riset Kesehatan Dasar. Badan Penelitian dan Pengembangan Kesehatan Kementerian Kesehatan RI: 2013.

Sanger, OG. Loho, MF. Wirasti. CR. Tesis Pengaruh Suntikan Depo Medoksiprogesteron Asetat terhadap Profil Lipid. Volume 32 No 03, FK Universitas Sam Ratulangi Manado: 2008.

Yadav, B.K., Gupta, R.K., Gyawali, P., Shrestha, R., Poudel, B., Sigdel, M. and Jha, B. 'Effects of long-term use of Depomedroxyprogesterone acetate on lipid metabolism in Nepalese women', The Korean Journal of Laboratory Medicine, 31(2), p. 95. doi: 10.3343/kjlm.2011.31.2.95. 